\title{
Cloning and sequencing of the celA gene encoding endoglucanase $A$ of Butyrivibrio fibrisolvens strain A46
}

\author{
Geoffrey P. Hazlewood, ${ }^{1 *}$ Keith Davidson, ${ }^{1}$ Judith I. Laurie, ${ }^{1}$ Marek P. M. Romaniec ${ }^{2}$ \\ and HARRY J. GILBERT ${ }^{3}$ \\ ${ }^{1}$ Department of Biochemistry, AFRC Institute of Animal Physiology and Genetics Research, Babraham, Cambridge \\ $C B 24 A T, U K$ \\ ${ }^{2}$ Fermentation Microbiology Laboratory, Department of Biology, Massachussetts Institute of Technology, Cambridge, \\ MA 02139, USA \\ ${ }^{3}$ Department of Agricultural Biochemistry and Nutrition, University of Newcastle upon Tyne, Newcastle upon Tyne \\ $N E 17 R U, U K$
}

(Received 5 April 1990; revised 3 June 1990; accepted 4 July 1990)

\begin{abstract}
Genomic DNA from Butyrivibrio fibrisolvens strain A46 was digested with EcoRI and ligated into גgt11. Two recombinant phages isolated from the gene bank hydrolysed carboxymethylcellulose and were shown to contain the same $2.3 \mathrm{~kb}$ EcoRI restriction fragment, which was cloned into pUC12 to generate pBA46. Escherichia coli JM83 harbouring pBA46 expressed an endoglucanase (EGA) which hydrolysed a range of other substrates including barley $\beta$-glucan, Avicel, filter paper and $p$-nitrophenyl $\beta$-D-cellobioside. Nucleotide sequencing of the $B$. fibrisolvens strain A46 DNA cloned in pBA46 revealed a single open reading frame (ORF) of 1296 bp, encoding a protein of $48863 \mathrm{Da}$. Confirmation that the ORF coded for EGA was obtained by comparing the $\mathrm{N}$-terminal sequence of the purified endoglucanase with that deduced from the nucleotide sequence. EGA contains a typical prokaryotic signal peptide at its $\mathrm{N}$-terminus and shows some homology with the Bacillus family of cellulases. The enzyme does not contain distinct functional domains, which are prevalent in cellulases from Pseudomonas fuorescens subsp. cellulosa and Cellulomonas fimi.
\end{abstract}

\section{Introduction}

Butyrivibrio fibrisolvens plays an important role in the ruminal breakdown of plant structural polysaccharides. In ruminants such as the high-arctic Svalbard reindeer, B. fibrisolvens is the major culturable cellulolytic bacterium in both summer and winter, representing $66 \%$ and $55 \%$ of the cellulolytic population respectively (Orpin $e t$ $a l ., 1985)$. In view of the well-documented involvement of members of this genus in a variety of rumen processes, it is surprising that their cellulase system has received so little attention. Kopecny (1986) reported that the cellulase of $B$. fibrisolvens UC142 comprised extracellular and cell-associated enzymes, including an endo-1,4- $\beta$ glucanase (EC 3.2.1.4) and three $\beta$-glucosidases (EC 3.2.1.21). More recently, an endoglucanase gene (end-1)

\footnotetext{
Abbreviations: EGA, endoglucanase A; ORF, open reading frame.

The nucleotide sequence data reported in this paper have been submitted to GenBank and have been assigned the accession number M37031.
}

from $B$. fibrisolvens $\mathrm{H} 17 \mathrm{c}$ was cloned and sequenced (Berger et al., 1989); the encoded protein was homologous with an endoglucanase (EGE) from Clostridium thermocellum.

Cellulase genes from a range of micro-organisms have now been sequenced, revealing considerable diversity in the molecular structure of these proteins (see Béguin, 1990 , for a review). Some bacteria synthesize enzymes whose structure is highly conserved, while others express cellulases which show little homology at the amino acid level. Cellulases produced by Pseudomonas fuorescens subsp. cellulosa (Gilbert et al., 1990), Cellulomonas fimi (Ong et al., 1989) and Bacteroides succinogenes (McGavin \& Forsberg, 1989) typically contain distinct structural regions responsible for cellulose binding and catalytic activity. In contrast, endoglucanases from Bacillus spp., Clostridium spp. (Béguin, 1990) and Ruminococcus albus (Poole et al., 1990) in general do not appear to contain substrate-binding domains distinct from the active site. Similarities in molecular architecture, and the conserva- 
tion of sequence between cellulases expressed by $B$. fibrisolvens remain to be elucidated.

A detailed knowledge of cellulases will contribute greatly to our understanding of fibre digestion in the rumen, and may also facilitate commercial exploitation of this important group of enzymes. With these objectives in mind, we describe here the cloning and sequencing of the celA gene from $B$. fibrisolvens strain A46, encoding endoglucanase A (EGA).

\section{Methods}

Bacterial strains, plasmids and culture conditions. B. fibrisolvens strain A46 was originally isolated from the rumen of the high-arctic Svalbard reindeer (Orpin et al., 1985), and was cultured statically at $39^{\circ} \mathrm{C}$ in rumen-fluid-containing medium (Hobson, 1969; medium 2) with cellobiose $(0.25 \%, \mathrm{w} / \mathrm{v})$ and carboxymethylcellulose (CMC; sodium salt, low viscosity, DS $>0.4 ; 0.25 \%$, w/v) as carbon sources. Escherichia coli strains HB101 (Boyer \& Roulland-Dussoix, 1969) and JM83 (Norrander et al., 1983) were cultured at $37^{\circ} \mathrm{C}$ in Luria broth (LB) adjusted to $\mathrm{pH} 7.5$ with $\mathrm{NaOH}$. Agar $(1.5 \%$, w/v), and filter-sterilized ampicillin $\left(100 \mu \mathrm{g} \mathrm{ml}^{-1}\right)$ and tetracycline $\left(12.5 \mu \mathrm{g} \mathrm{ml}^{-1}\right)$, were added as required. Vectors used for subcloning and sequencing the endoglucanase gene were pUC12, pUC18, pUC19, M13mp18 and M13mpl9 (Norrander et al., 1983). Plasmid pNM52, containing lacl ${ }^{4}$, was described by Gilbert $e t$ al. (1986).

Isolation of DNA. Total DNA from B. fibrisolvens strain A46 was extracted and purified as described by Romaniec et al. (1987). Largescale preparations of plasmid DNA were made from $E$. coli by alkaline lysis and purified by caesium chloride density-gradient centrifugation (Maniatis et al., 1982). The methods of Birnboim \& Doly (1979) and Holmes \& Quigley (1981) were used for small-scale plasmid DNA extraction and rapid screening of plasmid-containing clones. Largescale preparations of $\lambda$ phage DNA were made from liquid lysates essentially as described by Maniatis et al. (1982). E. coli Y1090 (Young $\&$ Davis, 1983), infected with recombinant $\lambda$ phage which had been recovered in agar plugs from $\mathrm{CMCase}^{+}$plaques, was cultured in NZB medium until lysis occurred. NZB medium contained $\left(\mathrm{g}^{-1}\right)$ : tryptone, 10; yeast extract, 5 ; maltose, $2 ; \mathrm{NaCl}, 5 ; \mathrm{MgCl}_{2} .7 \mathrm{H}_{2} \mathrm{O}, 2$.

Construction and screening of the genomic library. Genomic DNA from B. fibrisolvens strain A46 was digested with EcoRI and fragments 2$9 \mathrm{kbp}$ in size were recovered by electroelution and ligated into EcoRIdigested $\lambda$ gt 11 DNA (Young \& Davis, 1983) (Protoclone $\lambda$ gt 11 system, Promega Biotec), using conditions specified in the manufacturer's technical bulletin. In vitro packaging of the $\lambda$ DNA was done using protocol II of Maniatis et al. (1982). Recombinant phage (LacZ ${ }^{-}$) were enumerated by plating dilutions of phage suspension, mixed with $E$. coli $\mathrm{Y} 1090$, on NZB soft agarose medium supplemented with isopropyl $\beta$-D-thiogalactoside (IPTG; $100 \mu \mathrm{g} \mathrm{ml}^{-1}$ ) and 5-bromo-4chloro-3-indolyl- $\beta$-D-galactoside (X-Gal; $250 \mu \mathrm{g} \mathrm{ml}^{-1}$ ). For screening the gene bank, $\lambda$ recombinants (20000 in total) were cultured on lawns of $E$. coli $\mathrm{Y} 1090$ to a plaque density of $10 \mathrm{~cm}^{-2}$. Each plate was overlaid with medium containing $\mathrm{CMC}(0.5 \%, \mathrm{w} / \mathrm{v})$ and agarose $(1.5 \%, \mathrm{w} / \mathrm{v})$ in PC buffer ( 50 mM- ${ }_{2} \mathrm{HPO}_{4}, 12$ mM-citric acid, $\mathrm{pH} 6.5$ ), and incubated at $39^{\circ} \mathrm{C}$ for $16 \mathrm{~h}$. Plaques producing $\mathrm{CMCase}$ activity were identified by staining with Congo Red $(1 \%$, w/v) and destaining with $1 \mathrm{M}$-sodium chloride (Teather \& Wood, 1982). CMCase ${ }^{+}$plaques were removed in plugs of agar and phage contained therein were allowed to diffuse into $1 \mathrm{ml} \mathrm{SM}$ buffer $[10 \mathrm{mM}$ Tris $/ \mathrm{HCl}, \mathrm{pH} 7.8$, containing $100 \mathrm{mM}-\mathrm{NaCl}$, $20 \mathrm{mM}-\mathrm{MgCl}_{2}$ and $0.05 \%(\mathrm{w} / \mathrm{v})$ gelatin]
General recombinant DNA procedures. Agarose gel electrophoresis, transformation of $E$. coli and the modification of DNA using restriction enzymes and T4 DNA ligase were done essentially as described by Gilbert et al. (1987). Southern blot hybridization was performed according to Romaniec et al. (1987).

Nucleotide sequencing. The $2.3 \mathrm{~kb}$ EcoRI fragment carrying the $B$. fibrisolvens strain A46 celA gene in pBA46 (Fig. 1) was cleaved with Pvull and the two fragments generated $(0.8$ and $1.5 \mathrm{~kb})$ were each cloned into pUC18 and pUC19 which had been digested with EcoRI and PvulI. Sequential digestion of each insert from either end, with Bal31 exonuclease, was used to generate sets of nested deletions; the deleted fragments were cloned into $\mathrm{M} 13 \mathrm{mp} 18$ and $\mathrm{M} 13 \mathrm{mp} 19$ for nucleotide sequencing. An internal HindIII fragment of $0.14 \mathrm{~kb}$ (Fig. 1) was separately cloned into $\mathrm{M} 13$ for determining the sequence over the region of the $P v u I I$ site. Nucleotide sequence was determined using the dideoxy chain-termination method of Sanger et al. (1980), with the exception that T7 DNA polymerase (Tabor \& Richardson, 1987) was substituted for the Klenow fragment of DNA polymerase I. Sequences were compiled and ordered using the computer programs described by Staden (1980). The entire sequence of celA was determined in both strands.

Bal31 deletions. To delete the $5^{\prime}$ region of celA, pUC18 containing full-length $c e l A$ on a $1.4 \mathrm{~kb} \mathrm{ScaI-ClaI}$ fragment (Fig. 1) was linearized with $E c o$ RI, digested with Bal31, and rendered blunt-ended with T4 DNA polymerase (Hall et al., 1988). The truncated fragment was excised by digesting with $S p h \mathrm{I}$, and was ligated into pUC18 which had been cleaved with $S m a I$ and $S p h I$, such that the coding sequence of $c e l A$ was in frame with the N-terminus of lacZ. The ' $3^{\prime}$ end of celA was deleted by linearizing pUC18 containing celA on the same ScaI-ClaI fragment with $S p h \mathrm{I}$, before digesting with $\mathrm{Bal} 31$ and filling in with T4 DNA polymerase. The deleted fragment was excised with EcoRI and ligated into pUC18 previously digested with EcoRI and SmaI.

Assays. Cellulase-related enzyme activities were assayed at $37^{\circ} \mathrm{C}$ in PC buffer, $\mathrm{pH} 6.5$, with substrate concentration in the range 2.5 to $10 \mathrm{mg} \mathrm{ml}^{-1}$. Hydrolysis of acid-swollen cellulose (Sigmacell type 50 treated according to Wood, 1971), Avicel (PH105, FMC Corporation), barley $\beta$-glucan (Biocon, UK), CMC (sodium salt, Sigma), filter paper (Whatman no. 1), laminarin (Sigma), lichenan (Sigma) and the soluble fraction of oat spelt xylan (Sigma) was measured by following the release of reducing sugar colorimetrically using 3,5-dinitrosalicylic acid (Miller, 1959). Hydrolysis of the chromogenic substrates 4-methylumbelliferyl $\beta$-D-cellobioside and $p$-nitrophenyl $\beta$-D-cellobioside was estimated colorimetrically. One unit (U) of enzyme activity was defined as that which resulted in the liberation of $1 \mu \mathrm{mol}$ product per $\mathrm{min}^{-1}$. Qualitative measurement of endoglucanase activity was done either by incorporating CMC into LB agar or by overlaying LB plates of $E$. coli clones with PC buffer containing $0.5 \%(\mathrm{w} / \mathrm{v}) \mathrm{CMC}$ and $1 \%(\mathrm{w} / \mathrm{v})$ molten agar. After incubating at $37^{\circ} \mathrm{C}$, activity was revealed by staining with Congo Red. Protein was measured by dye binding (Sedmak \& Grossberg, 1977) or by the Lowry method, with bovine serum albumin as standard.

Fractionation of E. coli. Periplasmic and cytoplasmic fractions of $E$. coli clones harbouring celA were prepared as described previously (Hazlewood et al., 1990).

Purification of endoglucanase $A(E G A)$. E. coli JM83 harbouring fulllength celA cloned in pUC18 was cultured for $16 \mathrm{~h}$ at $37^{\circ} \mathrm{C}$ in $\mathrm{LB}$ containing ampicillin $\left(100 \mu \mathrm{g} \mathrm{ml}^{-1}\right)$. Cells from 3 litres of culture were collected by centrifugation and were resuspended in $50 \mathrm{mM}$ Tris/ $\mathrm{HCl}$ buffer, $\mathrm{pH} 8$, to approximately $1 / 30$ of their original volume. Cell-free extract prepared by ultrasonication was loaded onto an anion-exchange column (2.6 $\times 21 \mathrm{~cm}$; DEAE-Trisacryl M; IBF Biotechnics) which was eluted with a $0-500 \mathrm{~mm}-\mathrm{NaCl}$ linear gradient in $50 \mathrm{mM}-\mathrm{Tris} / \mathrm{HCl}$ 
buffer, pH 8. Fractions containing endoglucanase activity were pooled, dialysed against $10 \mathrm{mM}$-Tris/HCl buffer, $\mathrm{pH} \mathrm{8}$, and applied to a second column containing DEAE-Trisacryl $M$, which was eluted with a 100 $400 \mathrm{mM}-\mathrm{NaCl}$ linear gradient. Active fractions were dialysed as above and concentrated by vacuum evaporation.

Sequencing of EGA. EGA, partially purified by anion-exchange chromatography, was fractionated by SDS-PAGE $(10 \%$ acrylamide, $0.1 \%$ SDS) (Laemmli, 1970) and transferred to Immobilon PVDF (Millipore) by electroblotting. Putative EGA (47 kDa), stained with Page Blue G90, was excised from the transfer membrane and applied directly to a $470 \mathrm{~A}$ gas-phase sequenator equipped with a $120 \mathrm{~A}$ on-line PTH analyser (Applied Biosystems; Hunkapillar et al., 1983).

\section{Results and Discussion}

\section{Isolation and characterization of CMCase ${ }^{+}$clones}

The genomic library constructed by ligating EcoRI fragments of $B$. fibrisolvens strain A46 DNA into $\lambda$ gtl 1 had an insertion rate of the order of $70 \%$. Twentythousand $\lambda \mathrm{gt} 11$ recombinants were screened and two $\mathrm{CMCase}^{+}$plaques were found. DNA was isolated from phage recovered from each of these plaques and the $B$. fibrisolvens EcoRI restriction fragments were excised and ligated into pUC12. Restriction enzyme analysis showed that both plasmids contained the same $2 \cdot 3 \mathrm{~kb}$ EcoRI fragment, which could be cleaved with HindIII or PvuII, but was devoid of BamHI, BglII, PstI, SalI or SmaI sites (Fig. 1). In Southern blot hybridizations, a ${ }^{32}$ P-labelled probe prepared by nick-translation of pUC12 containing the cloned fragment (pBA46) hybridized with a single $2.4 \mathrm{~kb}$ EcoRI fragment of $B$. fibrisolvens strain A46 genomic DNA. The same probe also hybridized with genomic DNA digested with HindIII and PvuII in a manner which confirmed the physical map and indicated that the fragment had been cloned without deletion or rearrangement (data not shown); pUC12 alone was not homologous with $B$. fibrisolvens strain A46 genomic DNA.

\section{Subcloning and expression of celA in E. coli JM83}

The $2.3 \mathrm{~kb}$ EcoRI fragment carrying the celA gene was subcloned from pBA46 into pUC18 and pUC19 and transformed into $E$. coli JM83. In both orientations celA directed the synthesis of functional EGA, which suggests that the celA promoter is operative in $E$. coli. A $1.4 \mathrm{~kb}$ Scal-ClaI restriction fragment (Fig. 1) directed the synthesis of an active endoglucanase when cloned into pUC18, but not when inserted in the opposite orientation into pUC19; this finding indicates that the ScaIClaI fragment contains the protein-coding region of $c e l A$, but not the regulatory sequences of the gene, and confirms that celA is transcribed in the direction indicated in Fig. 1.

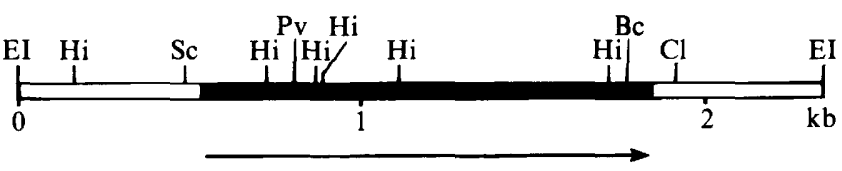

Fig. 1. Restriction enzyme map of B. fibrisolvens strain A46 genomic DNA in the vicinity of the celA gene. The positions of the cleavage sites for $B c I I(B c), C l a I(C l), E c o R I$ (EI), HindIII (Hi), PvuII (Pv) and ScaI (Sc) are shown. The extent and orientation of $\mathrm{CelA}$ are indicated by the solid bar and arrow respectively.

Table 1. Substrate specificity of EGA expressed in cell-free extract from $E$. coli JM83 harbouring full-length celA

The assays were repeated several times with different preparations. Typical results are shown.

\begin{tabular}{|c|c|}
\hline Substrate & $\begin{array}{l}\text { Specific activity } \\
{\left[U(\mathrm{mg} \text { protein })^{-1}\right]}\end{array}$ \\
\hline Acid-swollen cellulose & 0.009 \\
\hline Avicel & 0.006 \\
\hline Barley $\beta$-glucan & 1.4 \\
\hline $\mathrm{CMC}^{*}$ & 0.2 \\
\hline Cotton & 0.003 \\
\hline Filter paper & 0.0006 \\
\hline Laminarin & 0.004 \\
\hline Lichenan & 0.2 \\
\hline $\begin{array}{l}\text { 4-Methylumbelliferyl } \\
\beta \text {-D-cellobioside }\end{array}$ & 0.02 \\
\hline $\begin{array}{l}\text { 4-Methylumbelliferyl } \\
\beta \text {-D-glucoside }\end{array}$ & 0 \\
\hline$p$-Nitrophenyl $\beta$-D-cellobioside & 0.07 \\
\hline$p$-Nitrophenyl $\beta$-D-glucoside & 0 \\
\hline Xylan & 0.006 \\
\hline
\end{tabular}

* There was no significant difference between the activity displayed against high-, medium- and low-viscosity CMC.

When the ScaI-ClaI fragment cloned in pUC18 was transformed into $E$. coli JM83 already harbouring pNM52, a multicopy plasmid carrying the $l a c^{q}$ gene, transcription of the celA gene was brought under the control of $l a c Z p$, and high-level synthesis was induced by the addition of IPTG $(0.1 \mathrm{mM})$ to an exponential-phase culture; about $25 \%$ of the EGA synthesized under these conditions was secreted into the periplasm, and the total yield of EGA was considerably (6 to 10 times) higher than for $E$. coli JM83 harbouring the $2 \cdot 3 \mathrm{~kb} E c o$ RI fragment cloned into pUC18.

\section{Substrate specificity of $E G A$}

With respect to substrate specificity, EGA from $B$. fibrisolvens strain A46 was quite similar to Endl of $B$. fibrisolvens H17c (Berger et al., 1989). Enzyme contained in cell-free extracts made from $E$. coli harbouring cel $A$ was most active in hydrolysing barley $\beta$-glucan $(70-75 \%$ $\beta$-1,4-; 25-30\% $\beta$-1,3-linkages) (Table 1). Lichenan, a 
$-200$

ACAATATTAGAAATAAAAGAGTATGTTAATTCTCTTAGCAACGAGGAATTAGATAAGTTTATCGACGAGG

$-100$

TAGATTTTGCAGATTATGACTTCGATTTAGAGGCTCTTGATTTGCTTACAAGCTCACGTCTTTACGACTA

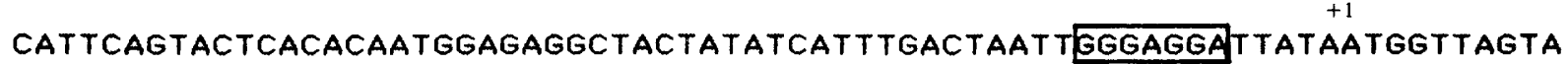

$M \quad S \quad S$

AGAAGCAGAAGTTCTTAACAGTCATACTTGTAATAGTTCTTGCTATAGTTATTGTTGGCGGAGTTTTTGG

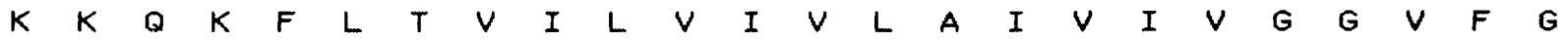

100

AATCAGCTTTGTTAAGGGCAGGGTTACTTTCCCTTGGCAGCTTCAAAATAGCGAAGCTAAAACTGAACAG $\begin{array}{lllllllllllllllllllllll}I & S & F & V & K & G & R & V & T & F & P & W & Q & L & Q & N & S & E & A & K & T & E & Q\end{array}$

GTGAAGGAGCCTGCAAAGGAAGAGCCTAAGCTTGTAATAAAGGAAAAGAACAGGACGAGTCCGCAAAAA GTGAAGGAGCCTGCAAAGgAAGAGCCTAAGCTTGTAATAAAGgAAAAGAAACAGgACGAGTCCGCAAAAA

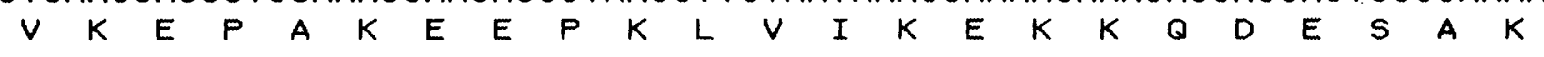

AGGAACAAGAGCTTAAGAAAGCCAAAGAAGAGgCAGAGGCAGCTGTAGAAAAAGAAACAGAAAAAACTGA $\begin{array}{llllllllllllllllllllllll}K & E & Q & E & L & K & K & A & K & E & E & A & E & A & A & V & E & K & E & T & E & K & T & E\end{array}$ 300 AGAAGAGCCTGTTGATAATCTTCTTAACGATATGAAGCTTAAATATTATGGCAAGCTTGCTGTTGAGgGT

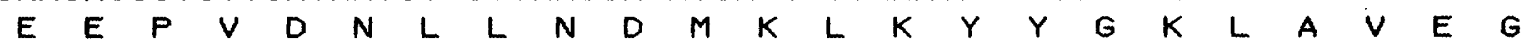
TCTCATCTTGTAGATGCAGATGGCCATGAGgTTCTTCTTATGGGCGTCAGCACTCATGGAATTAACTGGT

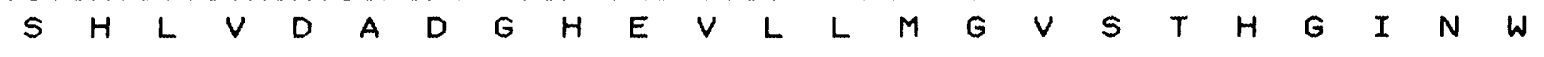

ATCCAGAATATGCTTCAGCAGAGACTATCAAATCCTTAAGAGATACCTGGGGCATCAATGTCATCAGACT $\begin{array}{lllllllllllllllllllllllll}Y & P & E & Y & A & S & A & E & T & I & K & S & L & R & D & T & W & G & I & N & V & I & R & L\end{array}$ 500 TGCTATGTACACAAGCGACTATAATGGTTATTGCGTGGCAGGTAAGGAAAACCAGGAAAAGCTTAAGGAT

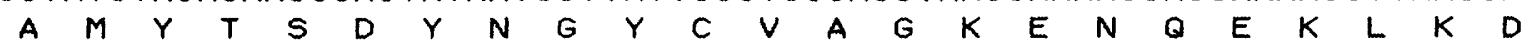

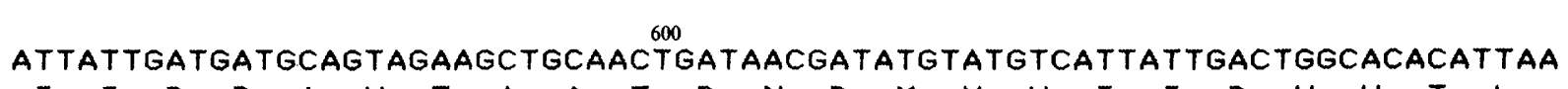
$\begin{array}{llllllllllllllllllllll}I & I & D & D & A & V & E & A & A & T & D & N & D & M & Y & V & I & I & D & W & H & T\end{array}$

ATGATGCAGACCCTAACGAATATAAGGCTGATGCTATTCAGTTCTTCGGTGAAATGGTGCGCAAATACAA

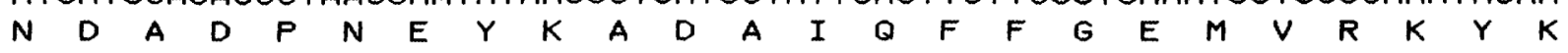

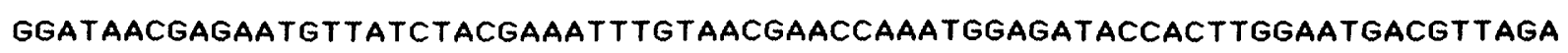

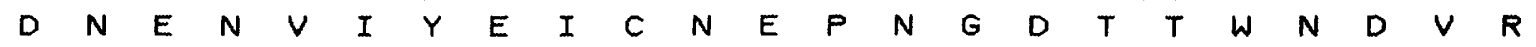
AgATACGCTAACGAGgTTATTCCGgTCATCAGAAATGTTGATGCTATCATTTTAGTGgGaACACCTAAGT

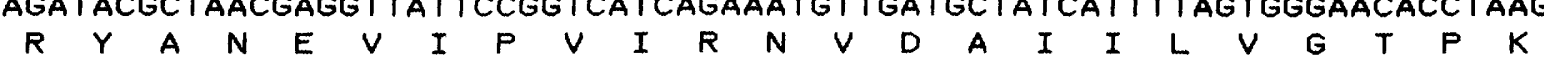


900

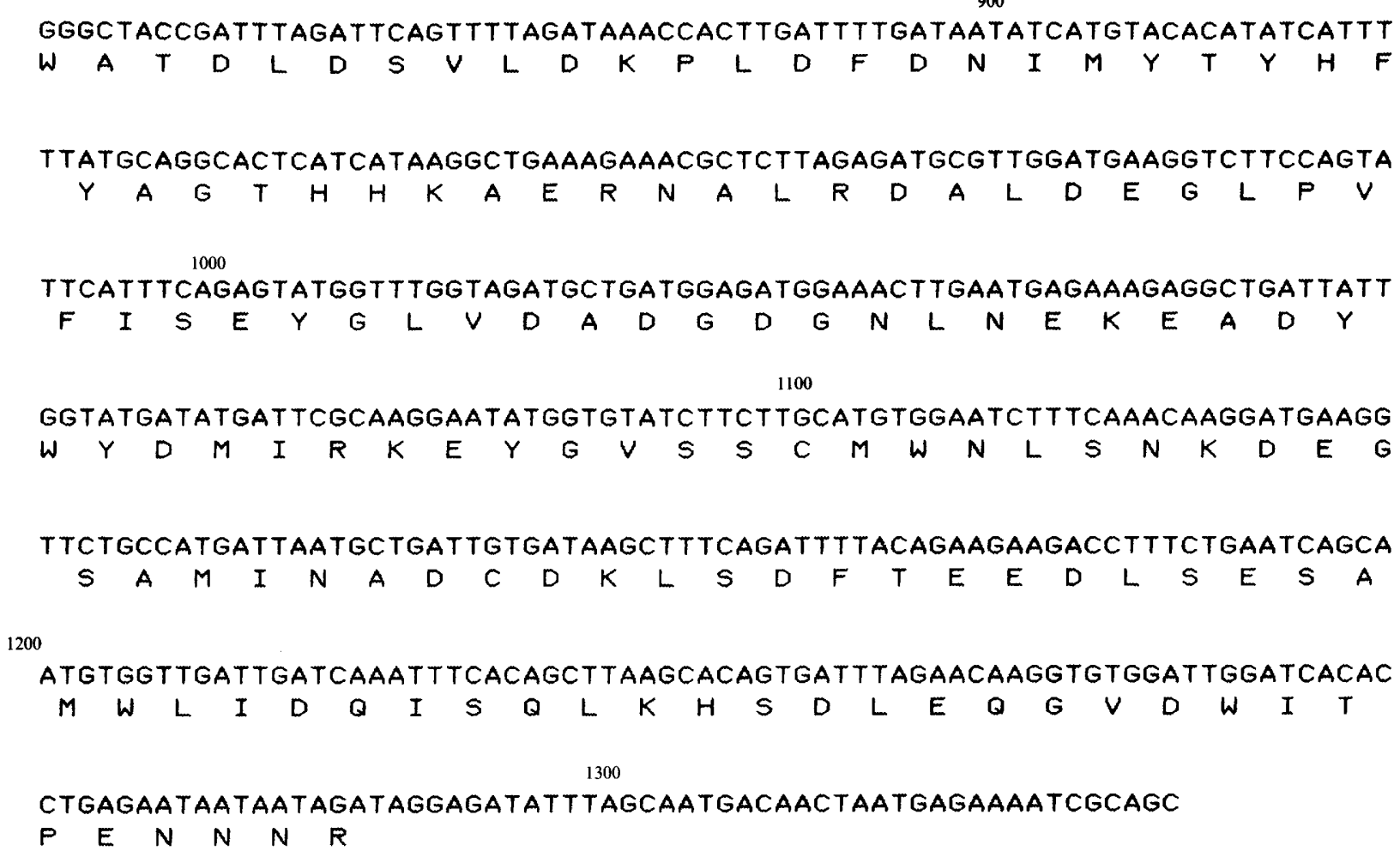

Fig. 2. Nucleotide sequence of the celA gene from $B$. fibrisolvens strain A46. The derived amino acid sequence of EGA is given in oneletter code. The signal peptide is indicated by a solid underline, and the broken underline shows the extent of the experimentallydetermined N-terminal sequence of mature EGA. The putative Shine-Dalgarno sequence is boxed.

similar mixed-linkage polysaccharide from Cetraria islandica was degraded to about the same extent as CMC. The enzyme also released reducing sugar during prolonged incubation with recalcitrant forms of cellulose (acid-swollen cellulose, Avicel, filter paper and cotton), but the activity against these substrates amounted to only $0.1 \%$ to $4 \%$ of the activity against CMC. A low level of activity was also observed against the soluble fraction from oat spelt xylan and against the $\beta$-1,3-linked polysaccharide laminarin (Table 1). Release of reducing sugar from CMC was accompanied by a rapid decline in substrate viscosity, characteristic of endo- $\beta$-1,4-glucanase activity. Cleavage of the aglycone bond in $p$-nitrophenyl $\beta$-D-cellobioside and 4-methylumbelliferyl $\beta$-D-cellobioside suggests that EGA also has some endoglucanase activity, but numerous other prokaryotic exoglucanases and xylanases also show activity against these substrates, so some caution is advisable in interpreting these results. No activity was detected against the aryl-glucosides $p$-nitrophenyl $\beta$-D-glucoside and 4-methylumbelliferyl $\beta$-D-glucoside.

\section{Nucleotide sequence of celA}

Translation of the nucleotide sequence of the $2.3 \mathrm{~kb}$ $E c o$ RI fragment cloned from $B$. fibrisolvens strain A46 revealed a single open reading frame (ORF) of $1296 \mathrm{bp}$ coding for a polypeptide of 432 amino acid residues, with a molecular mass of $48863 \mathrm{Da}$ (Fig. 2). The putative translation initiation codon was immediately preceded by a potential ribosome-binding site (GGGAGGA), and the $\mathrm{N}$-terminus of the polypeptide had the general characteristics of a prokaryotic signal peptide, being composed of a sequence containing 19 hydrophobic amino acids, preceded by a shorter sequence of positively-charged residues. Confirmation that the ORF codes for EGA was obtained experimentally by determining the molecular size and N-terminal sequence of EGA synthesized in E. coli JM83 harbouring full-length celA. Endoglucanase activity from cell-free extract, partially purified by anion-exchange chromatography and fractionated by SDS-PAGE, contained a major band corresponding to a molecular mass of $47 \mathrm{kDa}$ (data not 
Table 2. Codon usage of B. fibrisolvens strain A46 celA gene and B. fibrisolvens $H 17 \mathrm{c}$ end-I gene

\begin{tabular}{lrrrrrrr}
\hline \hline $\begin{array}{l}\text { Amino } \\
\text { acid }\end{array}$ & Codon & celA & end-1 & $\begin{array}{c}\text { Amino } \\
\text { acid }\end{array}$ & Codon & celA & end-1 \\
\hline F & TTT & 5 & 12 & S & TCT & 5 & 12 \\
F & TTC & 5 & 8 & S & TCC & 2 & 6 \\
L & TTA & 7 & 3 & S & TCA & 7 & 16 \\
L & TTG & 4 & 1 & S & TCG & 0 & 0 \\
L & CTT & 21 & 14 & P & CCT & 7 & 17 \\
L & CTC & 0 & 2 & P & CCC & 0 & 2 \\
L & CTA & 0 & 0 & P & CCA & 4 & 10 \\
L & CTG & 0 & 2 & P & CCG & 1 & 6 \\
I & ATT & 15 & 13 & T & ACT & 8 & 10 \\
I & ATC & 9 & 15 & T & ACC & 3 & 1 \\
I & ATA & 4 & 7 & T & ACA & 8 & 23 \\
M & ATG & 11 & 13 & T & ACG & 0 & 1 \\
V & GTT & 15 & 24 & A & GCT & 17 & 14 \\
V & GTC & 5 & 1 & A & GCC & 2 & 5 \\
V & GTA & 8 & 20 & A & GCA & 12 & 15 \\
V & GTG & 5 & 2 & A & GCG & 1 & 2 \\
Y & TAT & 14 & 19 & C & TGT & 2 & 2 \\
Y & TAC & 5 & 9 & C & TGC & 2 & 6 \\
Ter & TAA & 0 & 1 & Ter & TGA & 0 & 0 \\
Ter & TAG & 1 & 0 & W & TGG & 10 & 14 \\
H & CAT & 6 & 5 & R & CGT & 0 & 3 \\
H & CAC & 2 & 3 & R & CGC & 2 & 0 \\
Q & CAA & 4 & 0 & R & CGA & 0 & 0 \\
Q & CAG & 7 & 13 & R & CGG & 0 & 0 \\
N & AAT & 16 & 26 & S & AGT & 2 & 3 \\
N & AAC & 11 & 17 & S & AGC & 4 & 9 \\
K & AAA & 12 & 6 & R & AGA & 8 & 13 \\
K & AAG & 24 & 19 & R & AGG & 1 & 4 \\
D & GAT & 34 & 32 & G & GGT & 9 & 9 \\
D & GAC & 6 & 12 & G & GGC & 7 & 10 \\
E & GAA & 27 & 12 & GGA & 7 & 13 \\
E & GAG & 16 & 10 & GGG & 0 & 1 \\
\hline \hline & & & & & & & \\
\hline
\end{tabular}

shown). The $\mathrm{N}$-terminal sequence of this protein (VTFPQLQNSEAKTEQ) agreed with the sequence deduced for residues 35 to 50 of EGA (Fig. 2). The $\mathrm{G}+\mathrm{C}$ content of celA was $38.9 \mathrm{~mol} \%$; this compares with figures of 42 and $41.3 \mathrm{~mol} \%$ reported for the $\mathrm{G}+\mathrm{C}$ ratio of the $B$. fibrisolvens $\mathrm{H} 17 \mathrm{c}$ genome (Mannarelli, 1988) and the end-1 gene (Berger et al., 1989) respectively. Codons having $\mathrm{G}$ or $\mathrm{C}$ in the third position occurred in celA at frequencies of $18.6 \%$ and $15.2 \%$ respectively, indicating some bias towards $\mathrm{A}$ and $\mathrm{T}$ in the 'wobble' position. Synonymous codons were not utilized with equivalent frequencies in $c e l A$, but a comparison between this gene and end- 1 of $B$. fibrisolvens $\mathrm{H} 17 \mathrm{c}$ revealed that the two genes were quite similar in their codon preferences (Table 2). With two exceptions (AGA, GGA), both celA and end-1 make little use of those codons corresponding to the minor TRNAs which in E. coli are presumed to act as modulators (Minton et al., 1986).

\section{Sequence homology}

Comparison of sequences revealed that residues 151 to 283 of EGA had approximately $50 \%$ homology with Nterminal regions of endoglucanases from Bacillus sp. (Fukumori et al., 1989), Clostridium acetobutylicum (Zappe et al., 1988) and Erwinia chrysanthemi (Guiseppi et al., 1988) (Fig. 3). No homology was found with End-1 from B. fibrisolvens H17c. A classification based on hydrophobic cluster analysis has recently been employed to assign the cellulases of prokaryotic and lower eukaryotic organisms to six distinct families, some of which can be subdivided into subfamilies (Henrissat $e t$ al., 1989; Béguin, 1990). The subfamily A2 contains endoglucanases from Bacillus spp. and from C. acetobutylicum and Er. chrysanthemi. These endoglucanases show extensive homology over the entire length of their Nterminal catalytic domain, which comprises 300 to 400 


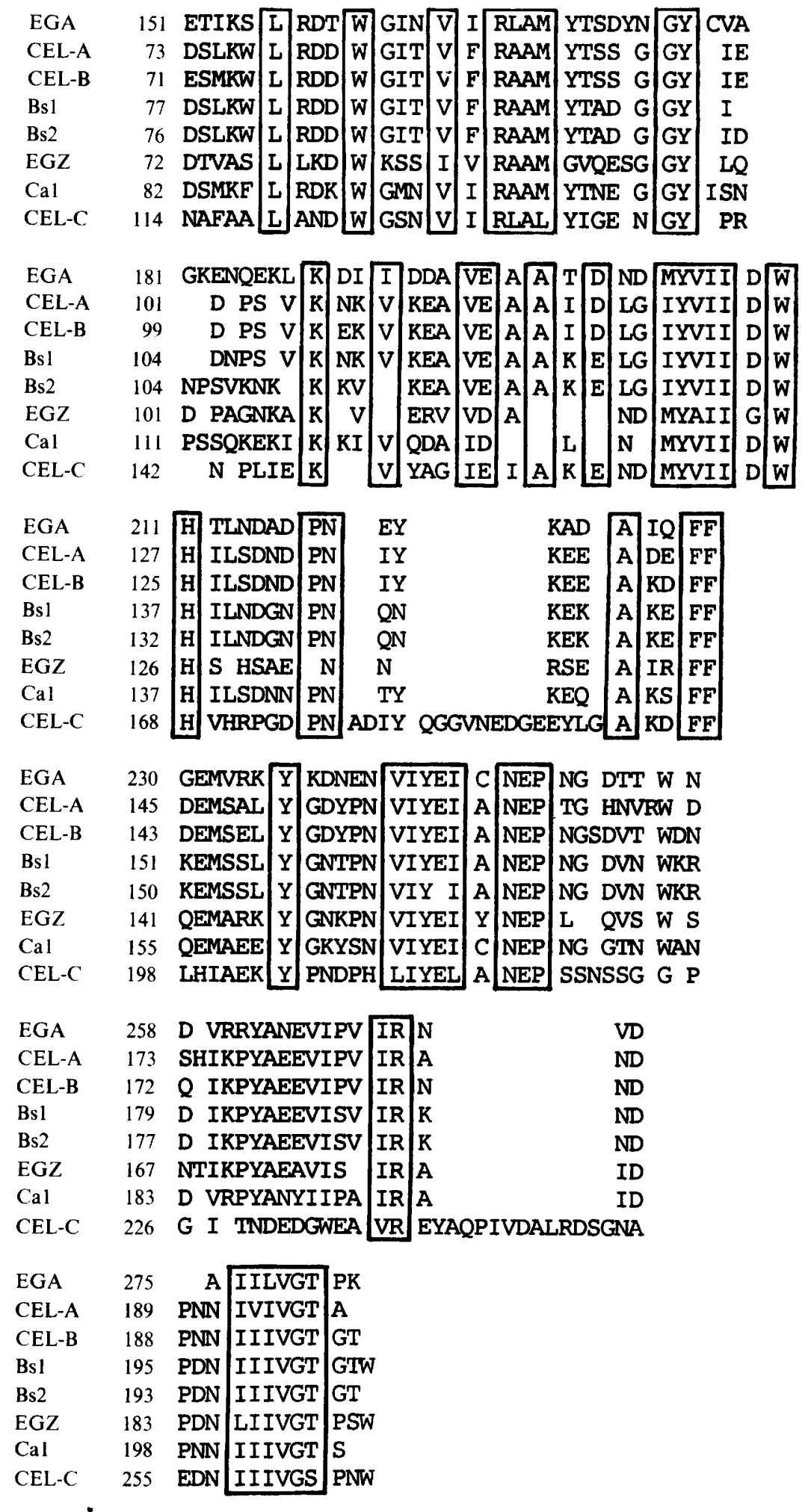

Fig. 3. Amino acid sequence alignments for endoglucanases from $B$. fibrisolvens strain A46 (EGA; this study), Bacillus sp. strain N-4 (CEL-A, CEL-B and CEL-C; Fukumori et al., 1989), Bacillus subtilis PAP115 (Bsl; Zappe et al., 1988), B. subtilis DLG (Bs2; Robson \& Chambliss, 1987), Erwinia chrysanthemi (EGZ; Guiseppi et al., 1988) and Clostridium acetobutylicum (Ca1 ; Zappe et al., 1988). Residues which are identical or similar in structure in all sequences compared are enclosed within a box. 
amino acid residues. Our finding that EGA displays significant homology with these enzymes suggests that the celA gene of B. fibrisolvens strain A46, like the other genes in the A2 subfamily, evolved from a common ancestral gene. Alternatively, conservation of sequence in cellulases from such a variety of species may have resulted from the convergent evolution of structures having a common function.

To date, the primary structures have been determined for five endoglucanases produced by anaerobic rumen bacteria. Cellulases from Ruminococcus albus are highly conserved (Poole et al., 1990), suggesting a common ancestral gene and strong selection pressure for the retention of conserved sequences. In contrast, the endoglucanases (EGA and End1) produced by two strains of $B$. fibrisolvens clearly belong to different cellulase subfamilies. This lack of homology between $B$. fibrisolvens cellulases could reflect the apparent ease with which genetic exchange occurs between members of this genus and other bacteria (Teather, 1985), thus providing a mechanism for the acquisition of cellulase genes from diverse sources. Alternatively, it may be further evidence of the inadequacy of the classification applied to rumen bacteria. If, as seems likely, rumen butyrivibrios comprise a genetically heterogeneous group consisting of two or more genera and numerous species (Hazlewood \& Teather, 1988) it would not be particularly surprising to find that their cellulase enzymes derive from more than one evolutionary source.

\section{Structure of $E G A$ in relation to function}

There is now clear evidence that the catalytic function of some prokaryotic cellulases is vested in a clearly defined independent catalytic domain which may account for less than half of the total gene (Béguin, 1990; Gilbert et al., 1990). In such cases, a substantial non-essential portion of the gene may be deleted without affecting the catalytic function of the encoded protein. To determine whether this is the case for EGA from $B$. fibrisolvens strain A46, truncated derivatives of celA were generated by digesting either the $5^{\prime}$ or the $3^{\prime}$ end of the gene with Bal31 exonuclease. Removal of $240 \mathrm{bp}$ from the $5^{\prime}$ end or $190 \mathrm{bp}$ from the $3^{\prime}$ end of celA resulted in complete inactivation of EGA. These results indicate that virtually the whole polypeptide is required to maintain the functional integrity of EGA. The apparent absence of a cellulose-binding domain distinct from the active site is supported by cellulose-binding studies (data not shown) which revealed that recombinant EGA produced by $E$. coli harbouring full-length $\mathrm{celA}$ did not bind strongly to Avicel in the manner typical of endoglucanases having distinct cellulose-binding domains (Gilbert et al., 1990; Ong et al., 1989).
Aspects of the molecular architecture of cellulases from the rumen species $B$. fibrisolvens, $R$. albus and Bacteroides succinogenes have now been reported. To date, only the latter organism has been shown to produce an endoglucanase containing a well-defined cellulose binding domain which is distinct from the catalytic centre (McGavin \& Forsberg, 1989). Fom an evolutionary viewpoint, the prospect of there being major differences between the cellulase systems of rumen bacteria is surprising, since all organisms evolving in the rumen have presumably been subjected to similar environmental influences. All three of these species are widely distributed in ruminants and are effective in degrading dietary cellulose. In vivo each is found colonizing plant tissue, but unlike Bac. succinogenes, $R$. albus and $B$. fibrisolvens produce cellulases which have not as yet been shown to contain functional cellulosebinding domains distinct from the active site, and form only a loose association with plant cell walls (Chesson \& Forsberg, 1988).

Future work by this group will focus on the mechanisms by which different bacterial cellulase systems hydrolyse plant cell wall polysaccharides in the rumen.

We wish to thank the AFRC (Grant no. LRG 138) for supporting this work.

\section{References}

BéGuIN, P. (1990). Molecular biology of cellulose degradation. Annual Review of Microbiology 44 (in the Press).

BERGER, E., JoNes, W. A., JoNes, D. T. \& WoODS, D. R. (1989). Cloning and sequencing of an endoglucanase (end1) gene from Butyrivibrio fibrisolvens H17c. Molecular and General Genetics 219, 193-198.

BirNBoIM, H. C. \& DolY, J. (1979). A rapid alkaline extraction procedure for screening recombinant plasmid DNA. Nucleic Acids Research 7, 1513-1523.

BOYER, H. W. \& RoullaNd-Dussorx, D. (1969). A complementation analysis of the restriction and modification of DNA in Escherichia coli. Journal of Molecular Biology 41, 459-472.

Chesson, A. \& Forsberg, C. W. (1988). Polysaccharide degradation by rumen microorganisms. In The Rumen Microbial Ecosystem, pp. 251-284. Edited by P. N. Hobson. London \& New York: Elsevier Applied Science.

Fukumori, F., Kudo, T., Sashihara, N., Nagata, Y., Ito, K. \& HORIKOSHI, K. (1989). The third cellulase of alkalophilic Bacillus sp strain $\mathrm{N}-4$ : evolutionary relationships within the cel gene family. Gene 76, 289-298.

Gilbert, H. J., Blazek, R., Bullman, H. M. S. \& Minton, N. P. (1986). Cloning and expression of the Erwinia chrysanthemi asparaginase gene in Escherichia coli and Erwinia caratovora. Journal of General Microbiology 132, 151-160.

Gilbert, H. J., Jenkins, G., Sullivan, D. A. \& Hall, J. (1987). Evidence for multiple carboxymethylcellulase genes in Pseudomonas fluorescens subsp. cellulosa. Molecular and General Genetics 210, 551-556.

Gilbert, H. J., hall, J., Hazlewood, G. P. \& Ferreira, L. M. A. (1990). The N-terminal region of an endoglucanase from Pseudomonas fluorescens subspecies cellulosa constitutes a cellulose-binding domain that is distinct from the catalytic centre. Molecular Microbiology 4, 759-767 
Guiseppi, A., Cami, B., Aymeric, J.-L., Ball, G. \& Creuzet, N. (1988). Homology between endoglucanase $\mathrm{Z}$ of Erwinia chrysanthemi and endoglucanases of Bacillus subtilis and alkalophilic Bacillus. Molecular Microbiology 2, 159-164.

Hall, J., Hazlewood, G. P., Barker, P. J. \& Gilbert, H. J. (1988). Conserved reiterated domains in Clostridium thermocellum endoglucanases are not essential for catalytic activity. Gene 69, 29-38.

HazlewoOd, G. P. \& TEaTHER, R. M. (1988). The genetics of rumen bacteria. In The Rumen Microbial Ecosystem, pp. 323-342. Edited by P. N. Hobson. London \& New York: Elsevier Applied Science.

Hazlewood, G. P., Davidson, K., Clarke, J. H., Durrant, A. J., HALL, J. \& GILBERT, H. J. (1990). Endoglucanase E, produced at high level in Escherichia coli as a lacZ fusion protein, is part of the Clostridium thermocellum cellulosome. Enzyme and Microbial Techno$\log y$ (in the Press).

Henrissat, B., Claeyssens, M., Tomme, P., Lemesle, L. \& Mornon, J.-P. (1989). Cellulase families revealed by hydrophobic cluster analysis. Gene 81, 83-95.

Hobson, P. N. (1969). Rumen bacteria. Methods in Microbiology 3B, 133-149.

Holmes, D. S. \& QUIGLEY, M. (1981). A rapid boiling method for the preparation of bacterial plasmids. Analytical Biochemistry 114, 193197.

Hunkapillar, M. W., Hewick, R. E., Dreyer, W. J. \& Hood, L. E. (1983). High sensitivity sequencing with gas-phase sequenator. Methods in Enzymology 91, 399-413.

KOPECNY, J. (1986). Cellulolytic enzymes of Butyrivibrio fibrisolvens. XIV International Congress of Microbiology, Abstract P.B17-25, p. 104.

LAEMMLI, U. K. (1970). Cleavage of structural proteins during the assembly of the head of bacteriophage T4. Nature, London 227, 680 685.

Maniatis, T., Fritsch, E. F. \& SAMbrook, J. (1982). Molecular Cloning: a Laboratory Manual. Cold Spring Harbor, NY: Cold Spring Harbor Laboratory.

MANNARELli, B. M. (1988). Deoxyribonucleic acid relatedness among strains of the species Butyrivibrio fibrisolvens. International Journal of Systematic Bacteriology 38, 340-347.

McGavin, M. \& Forsberg, C. W. (1989). Catalytic and substrate binding domains of endoglucanase 2 from Bacteroides succinogenes. Journal of Bacteriology 171, 3310-3315.

MILLER, G. L. (1959). Use of dinitrosalicylic acid reagent for determination of reducing sugar. Analytical Chemistry 31, 426-428.

Minton, N. P., Bullman, H. M. S., Scawen, M. D., Atkinson, T. \& GILBERT, H. J. (1986). Nucleotide sequence of the Erwinia chrysanthemi NCPPB1066 L-asparaginase gene. Gene 46, 25-33.

Norrander, J., Kemp, T. \& Messing, J. (1983). Construction of improved M13 vectors using oligodeoxynucleotide-directed mutagenesis. Gene 26, 101-116.
Ong, E., Greenwood, J. M., Gilkes, N. R., KilbuRN, D. G., Miller, R. C. \& WARREN, R. A. J. (1989). The cellulose-binding domains of cellulases: tools for biotechnology. Trends in Biotechnology 7, 239243.

Orpin, C. G., Mathiesen, S. D., Greenwood, Y. \& Blix, A. S. (1985) Seasonal changes in the ruminal microflora of the high-arctic Svalbard reindeer (Rangifer tarandus platyrhynchus). Applied and Environmental Microbiology 50, 144-151.

Poole, D. H., Hazlewood, G. P., Laurie, J. I., Barker, P. J. \& GILBERT, H. J. (1990). Nucleotide sequence of the Ruminococcus albus SY3 endoglucanase genes celA and celB. Molecular and General Genetics (in the Press).

Robson, L. M. \& Chambliss, G. H. (1987). Endo- $\beta$-1,4-glucanase gene of Bacillus subtilis DLG. Journal of Bacteriology 169, 2017-2025.

Romaniec, M. P. M., Clarke, N. G. \& Hazlewood, G. P. (1987). Molecular cloning of Clostridium thermocellum DNA and the expression of further novel endo- $\beta$-1,4-glucanase genes in Escherichia coli. Journal of General Microbiology 133, 1297-1307.

Sanger, F., Coulson, A. R., Barrell, B. G., SMith, A. J. H. \& Roe, B. A. (1980). Cloning in single-stranded bacteriophage as an aid to rapid DNA sequencing. Journal of Molecular Biology 143, 161-178.

Sedmak, J. J. \& Grossberg, S. E. (1977). A rapid, sensitive and versatile assay for protein using Coomassie Brilliant Blue G250. Analytical Biochemistry 79, 544-552.

StadeN, R. (1980). A new computer method for the storage and manipulation of DNA gel reading data. Nucleic Acids Research 16, 3673-3694.

TABOR, S. \& RICHARDSON, C. C. (1987). DNA sequence analysis with a modified bacteriophage T7 polymerase. Proceedings of the National Academy of Sciences of the United States of America 84, 4767-4771.

TEATHER, R. M. (1985). Application of gene manipulation to rumen microflora. Canadian Journal of Animal Science 65, 563-574.

TEATHER, R. M. \& Wood, P. J. (1982). Use of Congo Red polysaccharide interactions in enumeration and characterization of cellulolytic bacteria from the bovine rumen. Applied and Environmental Microbiology 43, 777-780.

Wood, T. M. (1971). The cellulase of Fusarium solani. Purification and specificity of the $\beta-(1 \rightarrow 4)$-glucanase and the $\beta$-D-glucanase components. Biochemical Journal 121, 353-362.

Young, R. A. \& DAvis, R. W. (1983). Efficient isolation of genes by using antibody probes. Proceedings of the National Academy of Sciences of the United States of America 80, 1194-1198.

ZAPPE, H., JoNES, W. A., JoNES, D. T. \& WoODS, D. R. (1988). Structure of an endo- $\beta$-1,4-glucanase gene from Clostridium acetobutylicum P262 showing homology with endoglucanase genes from Bacillus spp. Applied and Environmental Microbiology 54, 1289-1292. 